Journal of

Dentistry and Oral Health

\title{
Retrospective Research of Removing Dental Implants
}

\section{Dóra Iványi, Béla Czinkóczky, Péter Kivovics}

Semmelweis University, Department of Community Dentistry (Hungary, Budapest, 1088 Szentkirályi street 40.), Hungary

${ }^{*}$ Corresponding author: Dóra Iványi, Semmelweis University, Department of Community Dentistry (Hungary, Budapest, 1088 Szentkirályi street 40.), Hungary; E-mail: divanyi132@gmail.com

Received Date: April 02, 2019 Accepted Date: May 03, 2019 Published Date: May 06, 2019

Citation: Dóra Iványi (2019) Retrospective Research of Removing Dental Implants. J Dent Oral Health 6: 1-9.

\begin{abstract}
Aim: The purpose of this research is to make a comparative analysis of dental implant removals in the last five years in the Department of Community Dentistry.

Materials and methods: In the Department of Community Dentistry 74 implants of 39 patients were removed between 2014-2019. The relevant data were obtained by x-rays, medical charts and patient management program, called FOGÁSZ. Data were evaluated with Microsoft Excel software.

Results: The average age was $63.2 .63 .8 \%$ of the concerned individuals' inserted implants were removed. There is nearly equal share of the location of removed implants between the maxilla and the mandible. $20.0 \%$ of the patients lost their implants within six months from surgery. The removed implants were possessed 5.4 years long on average. $43.6 \%$ of the patients commanded fixed prosthesis supported implant and teeth, this was the most common prosthesis type. The prevalence of peri-implantitis around removed implants was $79.7 \%$. Out of the partly edentulous patients, horizontal bone resorption was discernible in $46.9 \%$.
\end{abstract}

Conclusion: Teeth and implant supported fixed prostheses may cause implant loss, because of the biomechanical aspects of anchoring behave differently in the bone. Lack of peri-implantitis is a key factor in the success of implants. Periodontitis could also encourage the development of peri-implantitis.

Clinical significance: Avoid planning prostheses anchored at the same time to tooth and implant. Sufficient oral hygiene is essential for the prevention of inflammation. Patients with periodontitis should be cured of inflammation before implantation.

Keywords: Endosseous dental implantation, Implant removal, Implants, Peri-implantitis, Research, retrospective study. 


\section{Introduction}

Nowadays, the use of implantation supported restorations have become a widely considered tooth replacement procedure in dentistry. With appropriate clinical and anatomical factors, each types of edentulous patients can undergo prosthetic treatments. Several types of dental implants are developed and used in dentistry however, this article will focus on endosseous root-form implants which are the most frequently applied in dentistry today. According to statistics the success rate of implantation is high nevertheless there are still considerable implant failures that might require implant removals. The aim of this retrospective study is to aid practising dentists by giving a comparative assessment of implant removals.

Literature shows that the success rate of implantation is within broad limits. According to certain authors, the survival proportion is about 90-99\% [1-4]. Different implantation related complications can occur. We may differentiate early and late complications which are related to implants. Complications can be cured by non-surgical or surgical therapy. In case the elected approach is ineffective the implant should be removed $[5,6]$. Indications of implant removal can be divided into two main groups: early and late indications. In the first case the implant removal happens before the osseointegration, and when the implant removal happens after the osseointegration we define it as late indication [7] (Table 1.)

\begin{tabular}{|c|c|}
\hline Early indications & Late indications \\
\hline $\begin{array}{l}\text { Tissue injury } \\
\text { - nerve injury } \\
\text { - tooth injury }\end{array}$ & $\begin{array}{l}\text { Biological indication } \\
\text { - peri-implantitis }\end{array}$ \\
\hline Malposition & $\begin{array}{l}\text { Mechanical indications } \\
\text { - implant fracture } \\
\text { - abutment fracture } \\
\text { - abutment screw fracture }\end{array}$ \\
\hline $\begin{array}{l}\text { Inadequate primary } \\
\text { stability }\end{array}$ & Concerning medical status \\
\hline Inflammation & Focal infection \\
\hline
\end{tabular}

Table1: Indications of removing dental implants

\section{Early indications}

Early indications involve tissue injury caused by implant placement. Temporary or permanent sensory impairment may derive from injuries to nerve trunks during implant surgery. Injuries may be treated medically or surgically depending on the extent of the pathological alterations and the neurological symptoms reported by the patient $[8,9]$. Along with nerve trunk injuries, tooth near the implant could be damaged.
Various therapies are available, tooth might be endodontically treated, extracted, otherwise implant may be removed [10]. In case of inadequate planning or procedure the implant might be malpositioned, which may also effect implant removal $[3,11]$. Appropriate imaging process, e.g. CBCT, can aid the most ideal implant placement. Implant removal could be suggested if the primary stability is inadequate. Too hard primary stability induces bone resorption around the implant, however implants' major amplitude micromovement caused by too low primary stability could inhibit osseointegration [12]. Mention must be made of the inflammatory processes before the osseointegration. Excessive temperature generation during surgical drilling and inefficiently controlled wound healing could result inflammation in the surrounding bone [13].

\section{Late indications}

Biological indication includes peri-implantitis. Peri-implantitis has been defined as an inflammatory process around an osseointegrated implant with progressive bone loss [14]. A study made in 2012 claims that the prevalence of peri-implantitis has been reported to be in the order of $10 \%$ of implants and $20 \%$ of patients [15]. Predisposing factors could be limited oral hygiene, smoking, systemic disease, poorly cleanable and overloaded prosthesis, history of peri-implantitis, soft tissue defects or poor quality soft tissue at the area of implants [16]. (Figure. 1.)

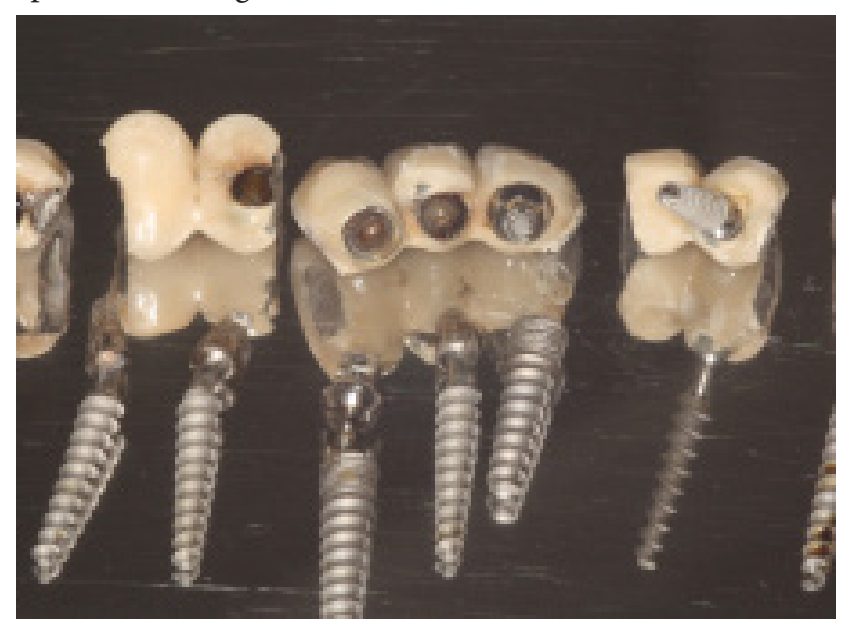

Figure 1: Implants were removed due to peri-implantitis.

The diagnosis of peri-implantitis requires: 1.) Evidence of visual inflammatory changes in the peri-implant soft tissues combined with bleeding on probing and/or suppuration; 2.) Increasing probing pocket depths as compared to measurements obtained at placement of the supra-structure; 3.) Progressive bone loss in relation to the radiographic bone level assessment at 1 year following the delivery of the implant- 
supported prosthetics reconstruction; 4.) In the absence of initial radiographs and probing depths, radiographic evidence of bone level $\geq 3 \mathrm{~mm}$ and/or probing depths $\geq 6 \mathrm{~mm}$ in conjunction with profuse bleeding represents peri-implantitis [17]. The treatment of peri-implant infections comprises conservative (non-surgical) and surgical approaches. Depending on the seriousness of peri-implant disease implant removal might be required [18].

Mechanical indications contain injury and fracture of the implant or the implants abutment. Most commonly, these conditions arise from implant overloading (Figure. 2.) [19]. Neither mechanical indications are absolute indications of implant removal [20].

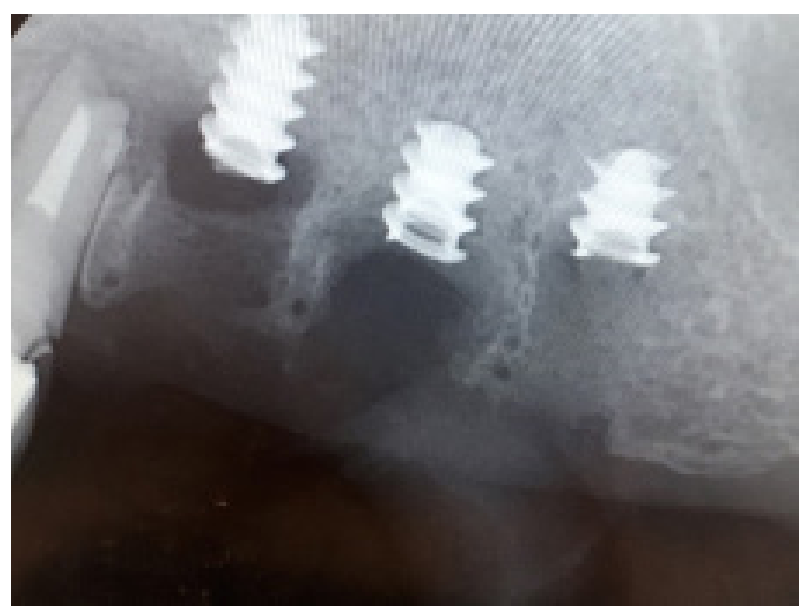

Figure 2. Implant fracture.

Indications of implant removal concerning medical status are divided into several groups. Implant removal might be suggested surrounding maxillofacial tumours, according to the oncologic treatment $[21,22]$. Removal should be measured about implants are qualified as focal infections.

On account of the actuality of the present argument the Department of Community Dentistry's workgroup proposed the investigation of implant removals. The aim of this research is to make a comparative interpretation of implant removals in the last three and a half years in the department. Our research implies the distribution of age and gender of the examined population, location of inserted and removed implant in the jaws, elapsed time between implantation and removal, the types of prostheses anchored by removed dental implants and complications occurring with removed implants.

\section{Material and methods}

The last five years, 39 patients' (23 women and 16 men) 74 implants were removed in the Department of Community Dentistry. $88.9 \%$ of removed implants were not inserted in the
Department. The applied data were obtained by x-rays, medical charts and patient management program, called FOGÁSZ, found in the Department of Community Dentistry. Data were evaluated with Microsoft Excel software.

\section{Results}

\section{Age distribution}

Average age of the examined population was 63.2 years (deviation is 9.9 years). Female's average age was 60.6 years (deviation is 14.0 years), whereas males was 64.2 years (deviation is 13.6 years). $94.9 \%$ of the patients were aged 50 or over. $30.8 \%$ were $51-60$ years old, $48.7 \%$ were between $61-70$ years, $15.4 \%$ were aged $71-80$ and only $5.1 \%$ were in age group 31-40.

\section{Implant position in the jaws}

An analysis of the inserted and removed implants locations within the jaws were made, considering laterality. 114 implants were placed to patients who got through implant removal, on average 2.9 implants (deviation is 2.7 ) per participant. Inserted implants' percental repartition is shown in Table 2. A (Table 2. A). 64.9\% of the concerned individuals' inserted implants were removed, counts 74 implants. 1.9 implants (deviation is 1.6) were removed per individual. Removed implants' percental repartition is shown in Table 2. B (Table 2. B). 58.1\% of removed implants located in the maxilla.

\section{Implants survival time}

Data about removed implant lifetime were available in 30 cases. $20.0 \%$ of the patients lost their implants within six months from surgery, mainly because of early indications. Out of $20.0 \% 6.7 \%$ had to be removed immediately afterward implantation. Percentage of the survival time of removed implants is given in Table 3. (Table 3) Removed implants were possessed 5.4 years (deviation is 4.1 years) long on average.

\section{Types of prostheses anchored by removed dental}

\section{implants}

This research extends to observe the distribution of the prostheses types anchored by removed implants. $43.6 \%$ of the patients commanded fixed prosthesis supported implant and teeth, $25.6 \%$ wore bridges anchored by dental implants, $15.4 \%$ wore full denture, $12.8 \%$ wore dental crown and merely $2.6 \%$ had all on four prosthesis type. 


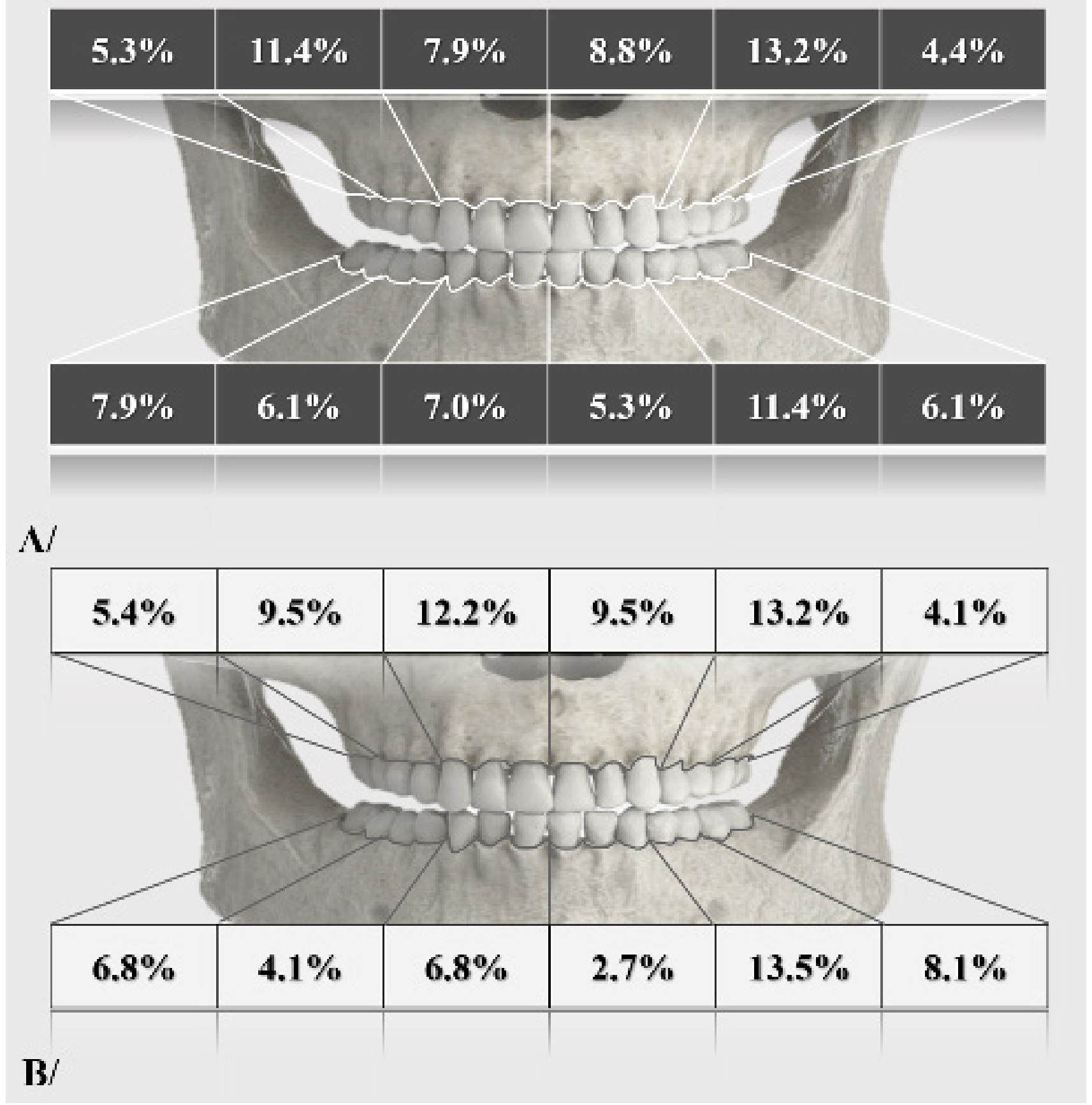

Table 2. A/ Inserted implants' percental repartition. B/ Removed implants' percental repartition. 


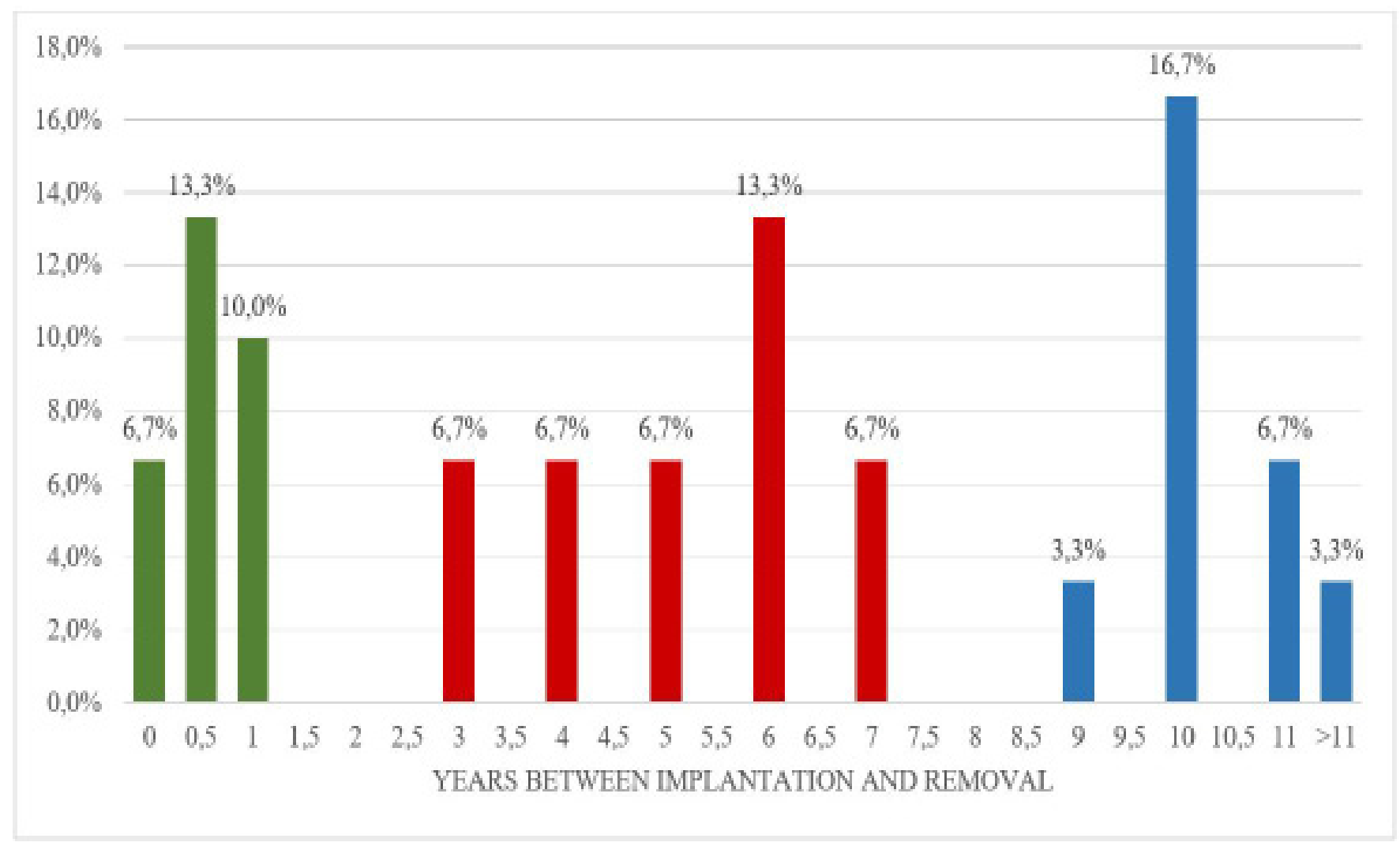

Table 3: Removed implants survival time.

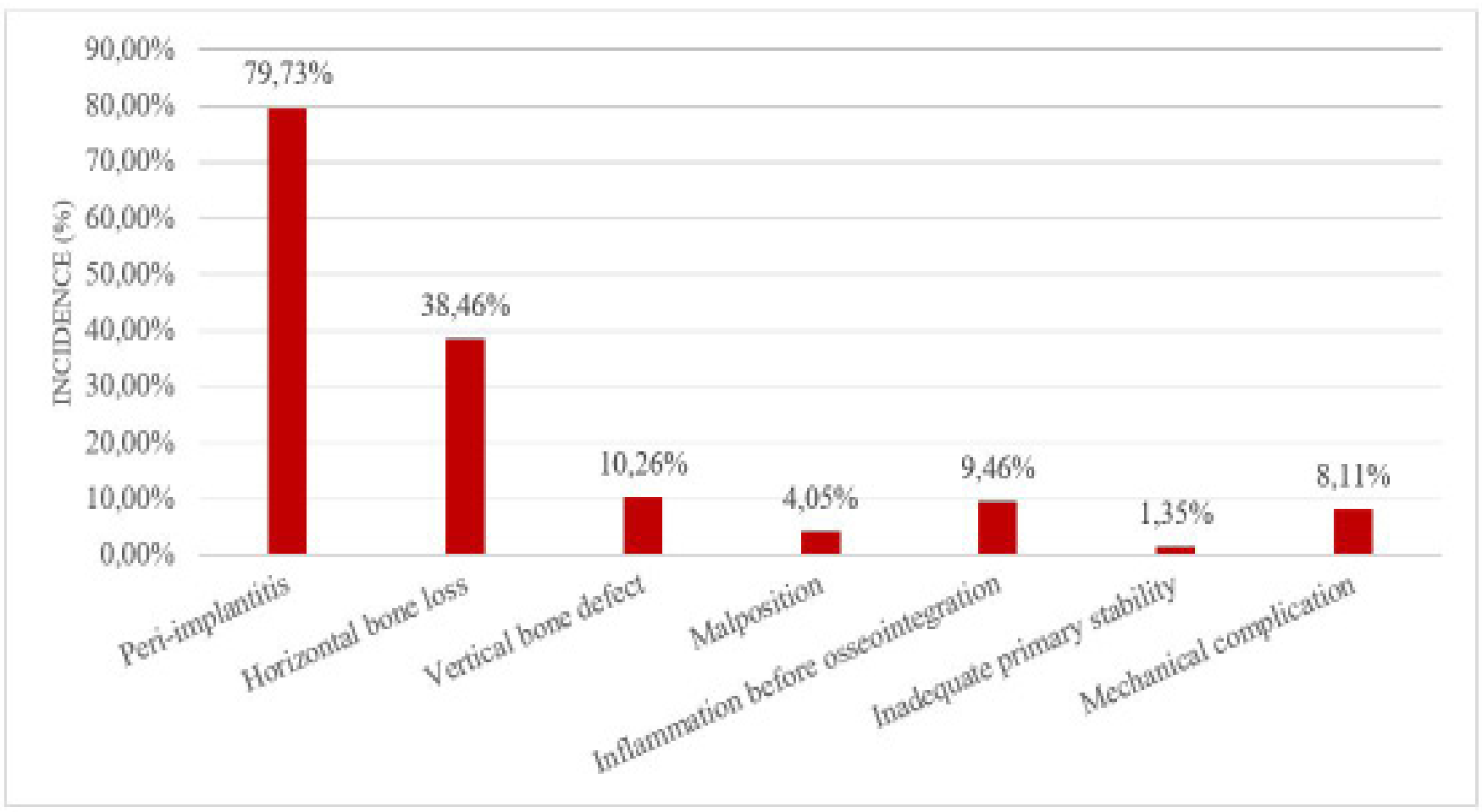

Table 4: Incidence of complications led to implant removal. 


\section{Complications concerning removed implants}

The prevalence of peri-implantitis around removed implants was $79.7 \% .20 .5 \%$ of the population was fully edentulous. Out of the remaining patients, horizontal bone resorption was discernible in $48.4 \%$, over and above vertical bone defect was detectible in $12.9 \%$. 9.5\% of the removals were recommended because of inflammation before osseointegration would have occurred. Only in tree cases were found malpositioned implants. 6 of 74 removed implants were explanted through mechanical indications (Table 4.).

\section{Discussion}

Over the age of 50, the prevalence of diabetes mellitus type two, cardiovascular diseases and tumorous diseases is rising $[23,24,25]$. Such morbi may decrease the resistance of the human body against bacteria and reduce the blood supply in different tissues, thus they might influence the undisturbed wound healing and the implant ossification. Accordingly, these common illnesses could be etiological factors in implant loss. According to a Hungarian study, the incidence of tooth loss is significantly growing over the age of 45 [26]. In parallel, the incidence of tooth loss, the rate of prosthesis is also in a tendency to increase [27]. As implantation supported prostheses are gaining ground in everyday dental practice, we can conclude that with traditional dentures, the prevalence of dentures on implants is also increasing in the older age group. Consequently, inference might be deducted, that the frequent implantation in elder population may also heighten the implant removals over the age of 50. In our opinion, the $94.9 \%$ incidence of people over 50 in the examined population cannot be explained with only the higher prevalence of systematic diseases.

Observation can be made into the location of inserted and removed implants. Notable difference is perceived between the right side in maxillary premolar, in the left side mandibular premolar and molar regions about removed implant's location. Further investigations and the number of cases need to be extended to determine the exact cause of the significant deviation measured in the different side regions. Removals in maxilla and in mandible were of nearly equal proportions. It should be noted that in large-scale studies, the proportion of placement of inserted implants does not match with sudden results [1]. In our case conclusion cannot be drawn, that the blood supply and structural differences in the maxillary and mandible affect the survival of the implants $[28,29]$. Further studies are needed to determine this inference.
Concerning the lifetime of removed implants, we can observe that there are three maxima in the time axis. The first spike is located in the first year from implantation. In these cases, implants were removed due to early indications. The second spike could be detected for 6 years. Among patients belonged to this group, hard-to-clean prosthesis had been frequent, and except of three patients, everybody had a fixed denture with anchored teeth and implants. It is assumed that peri-implantitis due to inappropriate design and construction of the prosthesis has increased the number of implant removals. The last spike appears in the time axis around 10 years. In these cases, almost all types of prosthetics have occurred. The additive effects of low risk etiologic factors involved in the formation of peri-implantitis might reach inflammation and bone resorption at 10 years that may indicate implant removal.

In the examined population, fixed prostheses anchored at the same time on implant and natural teeth was the most common type of prostheses anchored removed implants. Along with designing an implant supported prosthesis, the biomechanical properties of natural teeth, implants and anchored dentures must be taken into account. Natural tooth provides a flexible connection with bone by periodontal ligaments so fixed prosthesis on the tooth may have micromovements [30]. The connection among implants and bone is rigid and ankylotic. In the case of implant supported prosthesis, no or only very slight micromovements are observed. Micromovements generated by natural tooth are also transmitted to implants, assuming that the two types of anchoring are connected. Micromovement forces can weaken implant-bone relationship over time, helping penetration and adhesion of pathogens around implants, thereby promoting the formation of peri-implantitis [31,32]. The second most common type of prosthesis was fixed prosthesis anchored on implants. In many cases, the inappropriate design of prosthesis led to increased accumulation of dental plaque, which can provoke the formation of peri-implant inflammation, thus contributing to the loss of the implant [33,14]. (Figure. 3.) 


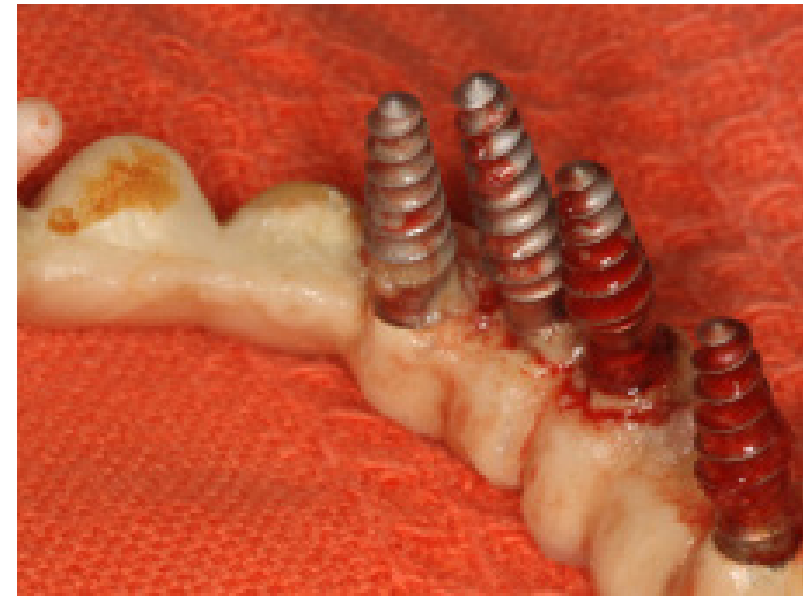

Figure 3: Dental plaque accumulated around implants due to inadequate dental prosthesis construction.

Peri-implantitis was observed nearly $80 \%$ of removed implants. High prevalence rates point to the fact that periimplantal inflammation is one of the most important factors for losing implants (Figure. 4.). The presence of certain etiologic factors contributes to the development of peri-implantitis, such as insufficient oral hygiene, smoking, inadequate loading of the implant, various systemic diseases, and inadequately designed or completed dentures [16]. Periodontitis could also promote the development of peri-implantitis. In patients suffering periodontitis, the incidence of peri-implantitis is six times greater, due to the fact that the anaerobic bacterial flora around sore implants and periodontally affected tooth are largely identical $[34,35]$. Horizontal bone resorption can be observed in $48.46 \%$ of patients. This confirms the assumption that there may be correlation between periodontal status and survival of implants. More than $10 \%$ of the removed implants were explanted due to inflammatory reactions before osseointegration. In these cases, the healing process might have been affected by traumatic surgical care, disturbed implant healing, dehiscence due to inadequate wound care and inadequate oral hygiene [36].

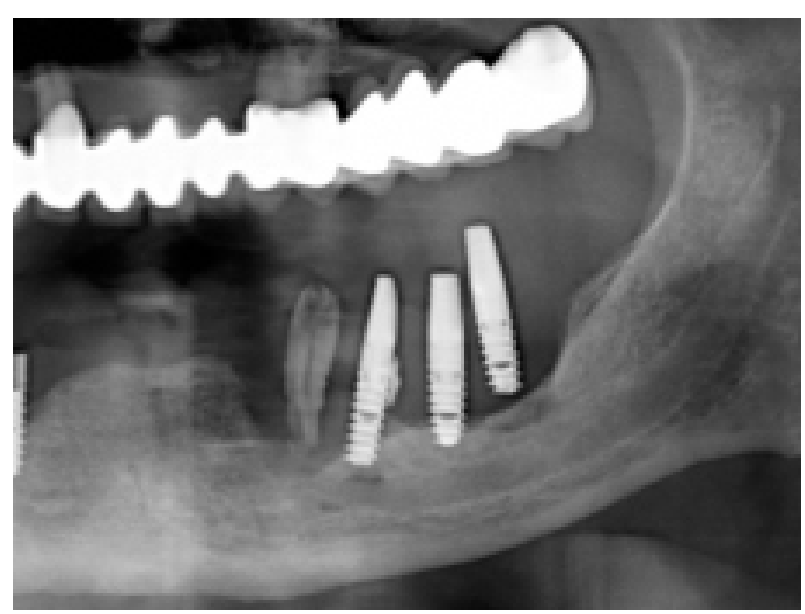

Figure 4: Seriously advanced peri-implantitis.

\section{Conclusion}

Based on our results, our conclusions were deducted:

- Avoid planning fixed prostheses supported at the same time by tooth and implant, because biomechanical aspects.

- In cases of implant supported fixed prostheses the aim is to give properly cleanable prostheses and to help create the patient's correct oral hygiene habits.

- Prevention of peri-implantitis is a key factor in the success of implants. We should try to minimize the presence of factors promoting the development of peri-implantitis. Sufficient oral hygiene is essential for the prevention of inflammation.

- $\quad$ Patients with periodontitis should be cured of inflammation before implantation. Thus, we can reduce the chance of periodontal anaerobic flora adhesion around the implant causing inflammation.

- An essential factor for osseointegration is the inflammation-free healing. We can choose our best-controlled wound healing technique for our patients, as we can best reduce the progression of inflammatory processes. 


\section{References}

1. Romeo E, Lops D, Margutti E, Ghisolfi M, Chiapasco M, Vogel G (2004) Long-term Survival and Success of Oral Implants in the Treatment of Full and Partial Arches: A 7-year Prospective Study with the ITI Dental Implant System. Int J Oral Maxillofac Implants 19:247-259.

2. Compton SM, Clark D, Chan S, Kuc I, Wubie BA, et al. (2017) Dental Implants in the Elderly Population: A LongTerm Follow-up. Int J Oral Maxillofac Implants 32:164-170.

3. Divinyi T (2007) Orális Implantológia. Budapest : Semmelweis Kiadó.

4. Grisar K, Sinha D, Schoenaers J, Dormaar T, Politis C (2017) Retrospective Analysis of Dental Implants Placed Between 2012 and 2014: Indications, Risk Factors, and Early Survival. Int J Oral Maxillofac Implants 32:649-654, 32:649-654 ed.

5. ITI Treatment Guide Volume 8. Bragger U, HeitzMayfield LJ (2015) Berlin, Germany: Quintessence Publisching Co.

6. Machtei, EE (2013) What do we do after an implant fails? A review of treatment alternatives for failed implants. Int J Periodontics Restorative Dent 33:111-119.

7. Iványi D and Kivovics P (2017) Possible causes and methods of removing dental implants 86 .

8. Alhassani AA, AlGhamdi AS (2010) Inferior Alveolar Nerve Injury in Implant Dentistry: Diagnosis, Causes, Prevention, and Management. J of Oral Implantology 36:401-407.

9. Auyong TG, Le A (2011) Dentoalveolar nerve injury. Oral Maxillofac Surg Clin North Am. 23:395-400.

10. Wook-Jae Y, Su-Gwan K, Mi-Ae J, Ji-Su O, Jae-Seek Y (2013) Prognosis and evaluation of tooth damage caused by implant fixtures. J Korean Assoc Oral Maxillofac Surg 39: 144-147.

11. Kahraman S, Bal BT, Asar NV, Turkyilmaz I, Tözüm TF (2009) Clinical study on the insertion torque and wireless resonance frequency analysis in the assessment of torque capacity and stability of self-tapping dental implants. J Oral Rehabil 36:755-761.

12. Javed F, Ahmed HB, Crespi R, Romanos GE (2013) Role of primary stability for successful osseointegration of dental implants: Factors of influence and evaluation. Interv Med Appl Sci 5: 162-167.

13. Scharf DR, Tarnow DP (1993) The Swedish system of osseointegrated implants: problems and complications encountered during a 4-year trial period. J Periodontol 64:954956.
14. Mombelli A, van Oosten M A, Schurch E Jr, Land N $\mathrm{P}$ (1987) The microbiota associated with successful or failing osseointegrated titanium implants. Oral Microbiol Immunol 2: 145-151.

15. Klinge B, Meyle J (2012) Peri-implant tissue destruction. The Third EAO Consensus Conference 2012. Clin Oral Implants Res 6:108-110.

16. Heitz-Mayfield, LJ (2008) Peri-implant diseases: diagnosis and risk indicators. J Clin Periodontol. 292-304.

17. S Renvert, G R Persson, F Q. Pirih, P M Camargo (2018) Peri-implant health, peri-implant mucositis, and periimplantitis: Case definitions and diagnostic considerations. Journal of Clinical Periodontology 20.

18. Heitz-Mayfield LJ, Needleman I, Salvi GE (2014)Consensus Statements and Clinical Recommendations for Prevention and Management of Biologic and Technical Implant Complications. The International Journal of Oral \& Maxillofacial Implants 29: 346-350.

19. Schwarz MS (2000) Mechanical complications of dental implants. Clin Oral Implants Res 1:156-158.

20. Ramsey AA (2010) Unusual Broken Dental Implant Corrected. Dr. Ramsey Amin's Page.

21. Yerit KC, Posch M, Seemann M, , Hainich S, Dörtbudak O, Turhani D, et al. (2006) Implant survival in mandibles of irradiated oral cancer patients. Clinical Oral Implants Research. 17:337-344.

22. Harrison JS, Strateman HS, Redding SW (2003) Dental implants for patients who have had radiation treatment for head and neck cancer. Special Care in Dentistry 23:223-229.

23. Jermendy Gy, Gaál Zs, Gerő L, Hídvégi T, et al. (2014) A diabetes mellitus kórismézése, a cukorbetegek kezelése és gondozása a felnőttkorban. Budapest : A Belgyógyászati Szakmai Kollégium és a Magyar Diabetes Társaság.

24. Széles Gy, Vokó Z, Jenei T, Kardos L, Ádány R, Lun K, et al. (2002) Kardiovaszkuláris betegségek morbiditási viszonyai Magyarországon.

25. Tompa, A (2011) A daganatos betegségek előfordulása, a hazai és a nemzetközi helyzet ismertetése. Magyar Tudomány 11: $1333-1344$.

26. Madléna M, Hermann P, Jáhn M, Fejérdy P (2008) Caries prevalence and tooth loss in Hungarian adult population: results of a national survey. BMC Public Health. 8:364. 
27. Fábián T, Fejérdy P, Somogyi E (1998) Evaluation of the dentition of the adult population in Hungary from the point of view of prothesis. Dental Reivew 91,383-389, 1998, 91: 383-389.

28. Chanavaz M (1995) Anatomy and histophysiology of the periosteum: quantification of the periosteal blood supply to the adjacent bone with $85 \mathrm{Sr}$ and gamma spectrometry. J Oral Implantol. 21:214-219.

29. Tolstunov L (2007) Implant zones of the jaws: implant location and related success rate. Journal of Oral Implantology 211-220.

30. Skalak R (2006) Biomedical Considerations in Osseointegrated Prostheses. The Journal of Prosthetic Dentistry 46: 843-848.

31. Winter W, Klein D, Karl, M (2013) Micromotion of Dental Implants: Basic Mechanical Considerations. Journal of Medical Engineering.

32. Charalampakis G, Leonhardt A, Rabe P, Dahlen G (2012) Clinical and microbiological characteristics of periimplantitis cases: a retrospective multicentre study. Clin Oral Implants Res 23:1045-1054.

33. Ericsson I, Persson LG, Berglundh T, et al. (1995) Different types of inflammatory reactions in peri-implant soft tissues. J Clin Periodontol 22: 255-261.

34. Zitzmann, NU, Walter, C és Berglundh, T (2006) Ätiologie, Diagnostik und Therapie der Periimplantitis - eine Übersicht. Deutsche Zahnärztliche Zeitschrift 61:642-649.

35. Rams TE, Degener JE, van Winkelhoff AJ (2013) Antibiotic resistance in human peri-implantitis microbiota. Clin Oral Implants Res 25:82-90.

36. Salonen MA, Oikarinen K, Virtanen K, Pernu H (1993) Failures in the Osseointegration of Endosseous. Int J Oral Maxillofac Implants 8:92-97.
Submit your manuscript to a JScholar journal and benefit from:

ब Convenient online submission

- Rigorous peer review

q Immediate publication on acceptance

ब Open access: articles freely available online

I High visibility within the field

ब Better discount for your subsequent articles

Submit your manuscript at http://www.jscholaronline.org/submit-manuscript.php 